\title{
Do Underwriters Create Value In The Determination Of The IPO Final Offering Price?
}

Barry Thornton, Jacksonville University, USA

Michael Adams, Jacksonville University, USA

George Hall, Jacksonville University, USA

\begin{abstract}
A company sets a price range in their "red herring" prospectus filed with the Securities and Exchange Commission when they issue shares for the first time. The firm's investment bankers then test the market to determine if the shares can be sold. The final offer price will be above, within or below the initial price range in the "red herring." This paper studies the first day price change and relates it to the final offering price being set below, within or above the initial price range. Based on six years (2002-2007) of market data, covering both bull and bear markets, it appears that investors might be able to realize higher percentage gains on the first day by investing in those stocks that are priced above the range indicated in the "red herring." Furthermore, the exchange on which the IPOs are traded also plays a significant role in the first day price change. We find empirical support for the partial price adjustment hypothesis of IPO underpricing and this finding is robust with respect to market regiments.
\end{abstract}

Keywords: partial price adjustment hypothesis, bookbuilding, asymmetric information theory, IPO underpricing, IPO offer price revisions, informational rents, IPO price discovery.

\section{INTRODUCTION}

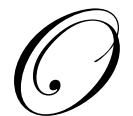

ne of the most difficult tasks confronting an investment banker involved in taking a firm public is the determination of an appropriate offer price for the issuing firm's stock. The information environment of IPO firms is limited. These firms have less public historical information, no secondary market and a much shorter operating history than publicly traded companies. IPO firms are also likely evaluated by buy-side Wall Street analysts to a much lesser extent. All of these factors increase the valuation uncertainty. Furthermore, it is costly for investors to attain information other than what is provided by investment bankers via the "red herring." This information asymmetry also creates uncertainty about the value of the firm. Nonetheless, the offer price is of great interest to the investment banker, the issuing firm, and those investors interested in purchasing the shares.

Perhaps one of the more puzzling phenomena in finance theory is the pervasive underpricing of initial public offerings (IPOs). The underpricing of IPOs has been a persistent market anomaly for many years, yet it still represents an enigma to the efficient market proponents. This paper reexamines the relationship between IPO offering price revisions and the underpricing of IPO shares. The study of IPO underpricing is salient because it raises important questions concerning market efficiency and the existence of systematic stock patterns that can be employed by investors to generate excess market returns.

Historically, IPOs have consistently been underpriced on average. The underpricing phenomenon refers to the abnormal returns found on the first day return on new shares traded in the secondary market. The abnormal first day return is measured as the percentage difference between the public offering price in the primary market and the closing price at the end of the first day of trading in the secondary market. Since this holding period return is based on only one day, the returns have not been adjusted by any market factor. Moreover, the initial IPO underpricing 
market anomaly is limited not only to the U.S. IPO market. Previous empirical research has confirmed that consistently positive first day IPO returns exist in virtually all global capital markets, albeit the magnitude of underpricing can vary significantly from one country's markets to another (Aggarwal, Leal and Hernandez, 1993).

\section{LITERATURE REVIEW}

When initial public offerings (IPOs) are sold in the primary market, they are often significantly underpriced in the market and exhibit substantial positive first day returns. These first day returns averaged $12.3 \%$ for the years 2002-2007 (Ritter, 2008). This return is especially perplexing since this abnormal first day return tends to be "undone" in subsequent months of trading, as the IPOs in general tend to underperform stocks of matched samples over the longer run (Loughran and Ritter, 1995). There is no general consensus on what can explain this apparently deliberate underpricing of IPOs. Some underpricing theories argue that IPO underpricing is due to the information asymmetry that exists between the issuers/underwriters and investors (Rock, 1986), while others suggest that underpricing is allowed because it signals the market (informed investors) concerning the overall quality of the newly issued shares (Leland and Pyle, 1977). IPO share underpricing also is alleged to be used to help reduce potential legal liability of the underwriters and issuing firm (Tinic, 1988), decrease the issue's marketing costs (Habib and Ljungqvist, 2001), or as Beatty and Ritter (1986) have suggested, it may simply reflect ex-ante uncertainty relative to the intrinsic value of the firm.

The key parties to the IPO transaction are the investors, both in the primary and secondary market, the issuing firm, and the bank underwriting the deal. The asymmetric information theory for IPO underpricing has received the strongest support in the literature. At the heart of this theory is the assumption that one of the three parties to the IPO is better informed than the others. For example, Baron (1982) posits that the investment banker has more knowledge about the actual market demand than either the issuing firm or investors. This principal-agent problem leads to the practice of employing underpricing as a means to increase investors' demand for the shares. The underwriter is assumed to be sufficiently well informed so as to be able to set the offer price below the fundamental (market) value of the security, ergo implying the initial windfall (shortfall) to the investors (issuing company) is largely intentional and undertaken deliberately. If the assumption of perfect foresight by the underwriters is correct, then their adjustments to the final offering price suggest that they actually reduce proceeds to issuing firms by deliberately offering the firm's stock at below market value.

Welch (1989) assumes that the issuing firm is more knowledgeable about its true economic worth than either the underwriter(s) or the investor(s). Higher-valued firms could employ underpricing as a strategy to send a signal to the capital markets about the true worth of the stock issue, especially if they envision future secondary offerings. The signaling theories of Allen \& Faulhaver (1989), Grinblatt and Hwang (1989), and Welch (1989), suggest that even if the management of the issuing firm has superior knowledge about its true value, they often voluntarily choose to deliberately underprice the new issue. This underpricing may simply be a way to create strong demand for the shares in accordance with the optimal ownership structure theory of Breen \& Franks (1997) and Stroughton and Zechner (1998). Rock (1986) found that some investors are more knowledgeable and as a result can avoid participating in IPOs that are overpriced, thereby avoiding Akerlof's (1970) classic lemon problem and avoiding the "winners curse." Akerlof demonstrated that if buyers cannot verify the quality of a product, they should always believe that a product is worth less than the price offered by the seller.

Rock (1986), along with Benveniste and Spindt (1989) suggest that sophisticated (informed) investors know more about the real market value of the offering than either the issuing firm or the underwriter. These investors, generally institutional investors as opposed to "noise" traders, supply the underwriters with private market information during the filing period's bookbuilding efforts. As a result, it is theorized that underwriters reward these professional investors by compensating them in the form of price discount in exchange for the private information they provide, quid pro quo. This price discount is accomplished by the underwriter not fully incorporating the information provided by investors into the final offer price.

In Benveniste and Spindt's model, underwriters collect information for price discovery from informed investors during the book-building process. Underpricing represents the informational rents that underwriters pay to institutional investors to disclose truthful information about the market value of the issue. The partial updating 
hypothesis states that private information revealed by these informed investors during the filing period is only partially reflected in final offering prices. These institutional investors or "smart money investors" are compensated for the private information they provide by deliberately underpricing the offering. This deliberate underpricing allows investors who are allocated shares to earn excessive first trading day returns. The payoff occurs when they are allocated shares and are allowed to flip the shares in the secondary market. Lowry and Schwartz (2004) find empirical support for Benveniste and Spindt (1989), by showing that underwriters do not fully adjust offer prices for all private information acquired prior to the offering date. Changes in publicly available information cannot fully explain the positive correlation between the adjustment in the final offering price and the median filing range price and realized IPO first day returns, so private information extraction appears to play an important role in the underwriter's final pricing decision.

Hanley (1993) was the first researcher to demonstrate that adjustments to the offer price range provide information about expected returns in the secondary market. This research demonstrated that an increase in the offer price above the initial filing range was directly correlated to positive first-day initial returns. This is consistent with the view that investors react to the new information provided by the underwriter. Hanley notes that "Underpricing is positively related to revisions in the offer price from the filing of the preliminary prospectus to the offer date" (Hanley, 1993, p. 243). She found that the final offer price revision to the range of anticipated offer prices disclosed in the red herring is a good indicator of the first day trading returns. Issues with final offer prices in excess of the upper limit of the IPO offer range have significantly more underpricing than other initial public offerings. There is also a positive correlation between these same offerings and the firm's desire to increase the number of shares issued by the firm. These results are consistent with the pricing and allocation schedule proposed by Benveniste and Spindt (1989), in which shares in an offering are rationed and the final offer prices have only been partially adjusted to reflect the new information provided during the book-building process.

Lowry and Schwert (2004) also confirm the existence of a significant positive correlation between offering range price revisions and the IPO returns earned in the market. However, they found that this price revision/return correlation is economically negligible. Further, they suggest that the midpoint of the filing range does not represent an unbiased predictor of the final offer price, as assumed in prior research. Loughran and Ritter's (2002) empirical findings indicate that the underwriters appear to reward all buyers (both professionals and "noise" traders) at the issuer's expense.

Boehmer and Fishe (2001) also considered the relationship between price range amendments and initial IPO returns. They argue that IPO underpricing is the cost of providing information and demonstrate that institutions also obtain more allocations in IPOs that perform better long-term. In a subsequent study, Bradley and Jordan (2002) obtain similar results to Loughran and Ritter. They demonstrate that any decreases in IPO file range in an amended prospectus has a much smaller effect on IPO initial returns than comparable increases in the filing range, ceteris paribus. Bradley and Jordan (2002, p. 603) stated that "this relation is significantly positive but convex, in that it is stronger for positive than for negative range amendments." These findings would appear to suggest that underwriters may deliberately set the IPO proposed price ranges low in the "red herring," in order to affect the impact of subsequent price revisions.

\section{IPO PRICING PROCESS}

When the "red herring" prospectus is submitted to the Securities Exchange Commission (SEC), the underwriter must include a proposed price range for the stock to be issued. As the prospectus is made available to potential investors, the underwriter gets a better sense of the demand for the IPO. This process of determining investor interest is called "bookbuilding." There is a minimum period of 20 days between when the IPO's prospectus is filed with the SEC and the sale of the new issue can take place. During this period of time, investment bankers can inform prospective investors about the IPO and try to determine the demand for the issue. If, during the road show, it appears likely that potential investor demand will be high, the offer price can be set above the upper value of the filing range provided in the "red herring" prospectus. Similarly, if it seems probable that investor sentiment for the new issue will be low; the final offer price can be set below the lower value of the filing range in the prospectus submitted to the SEC. Of course, the offer price can be set inside the initial filing range as well. 
The underwriter/issuer has the greatest price flexibility before the IPO is declared effective by the SEC. During this time period, pre-effective amendments to the price range may be filed. Generally, the underwriter may set the offer price up to 20 percent above the maximum price range value. However, the issuer may exceed this limit if the SEC does not view the price change as "substantive," since this allows the underwriter to file a prospectus supplement instead of a post-effective amendment. Additionally, there is a great deal of flexibility in setting the final offer price because the SEC has viewed a 30 to 40 percent change as non-substantial in the past.

Even after the issue is declared effective, there still exists some degree of flexibility beyond the maximum price range. Generally, the underwriter has the discretion to change the offer price or the size of the issue even after the IPO is declared effective, provided the total proceeds of the offering are within a 20 percent price range limit. For example, the offer price may change by 50 percent, as long as the issue size is adjusted in such a way as to stay within the 20 percent capitalization limit (SEC Regulations 457(a)).

Pricing an IPO too high has consequences for all three parties concerned with both the pricing of the IPO and the allocation of shares. The issue might be undersubscribed, leaving the investment banker with an inventory of unsold shares. The issuing firm may not be able to raise the desired amount of capital if all the shares can't be sold at the offer price. Finally, the investor may miss out on the first day increase in price that he or she desires. Pricing an IPO too low also causes problems, in particular for the issuing firm. An underpricing of the newly issued shares may leave a considerable amount of "money on the table." Consistently underpricing IPOs may reflect poorly on the underwriter's abilities in this area, resulting in a future loss of business. In spite of the problems of underpricing IPOs, there is substantial evidence to suggest that this is a common occurrence. It is often stated that an underpriced issue stimulates total investor demand.

If the IPO bookbuilding effort is successful, and there is high demand for the IPO shares, the lead investment banker can revise the offering price range upward to reflect the greater perceived demand. Similarly, if the deal appears to be in trouble, the price range can be adjusted downward. In either case, the final offer price can be made above, within or below the new price range as appropriate. It is interesting to note that in situations where the offering price range has been revised upward and the price has been set at the higher level, IPOs have a significantly higher mean first day gain.

This has been referred to as the "partial adjustment phenomenon" by Ibbotson, Sindelar and Ritter (1988) and is a function of the bookbuilding process. The term 'walk up' has been coined to deal with situations where the initial price range is set deliberately low. Bankers build up demand for the shares, and then increase the price range because of substantial investor interest. The pricing momentum helps create the appearance of a "hot" issue. Then when pricing, the bank sets the price just below the maximum point in the range, creating a "feel good" factor for investors who end up believing they have bought into a popular stock at a discount.

One issue worth investigating is why investment banks don't increase the offering price by an even greater degree. Underwriters cause the issuers and selling shareholders to leave significant amounts of money on the table a benefit to investors but detrimental to the issuers and selling shareholders. The tendency to underprice makes newly issued shares extremely attractive to investors, especially those hoping for a large increase in price on the first day. Usually their plan is to turn the stock over quickly, often as soon as the end of the first day. For these investors, the first day percentage change in price of a new issue is of paramount importance. The purpose of this paper is to determine if there is any relationship between the first day percent change in the price of a new issue and whether the actual offer price of the new issue is above, below, or within the range of prices provided in the prospectus filed with the SEC. If a relationship exists, it provides a tool that can be exploited by investors looking to make money by selling shares of the IPO on the first day of issue.

\section{METHODOLOGY AND DATA}

A sample of 990 IPOs issued from 2002-2007 was used to examine the behavior of the first day percent increase in price (FDPCP). The data were obtained from Renaissance Capital's IPOhome.com and Hoovers. Descriptive statistics for FDPCP can be found in both Table 1 and the corresponding boxplot in Figure 1. FDPCP is broken down by whether the final offer price was set below, within, or above the values of the filing range stated in 
the preliminary prospectus. It can be seen that the mean value of FDPCP in the above category is higher than the mean value of FDPCP in the within category, which is above the mean value of FDPCP in the below category. This suggests that an investor interested in a one day "flip" of an IPO should try to invest in one where the final offer price is set above the initial filing range.

Table 1: Descriptive Statistics for FDPCP

\begin{tabular}{|c|c|c|c|c|}
\hline \multicolumn{2}{|c|}{} & \multicolumn{3}{|c|}{ First Day Percent Change in Price } \\
\hline Final Offer Price & n & Mean Return & Median Return & Standard Deviation \\
\hline Below & 329 & $1.767 \%$ & $0.125 \%$ & $8.849 \%$ \\
\hline Within & 337 & $7.737 \%$ & $4.615 \%$ & $12.736 \%$ \\
\hline Above & 324 & $23.87 \%$ & $18.260 \%$ & $21.28 \%$ \\
\hline Total & 990 & $11.033 \%$ & $5.769 \%$ & $17.755 \%$ \\
\hline
\end{tabular}

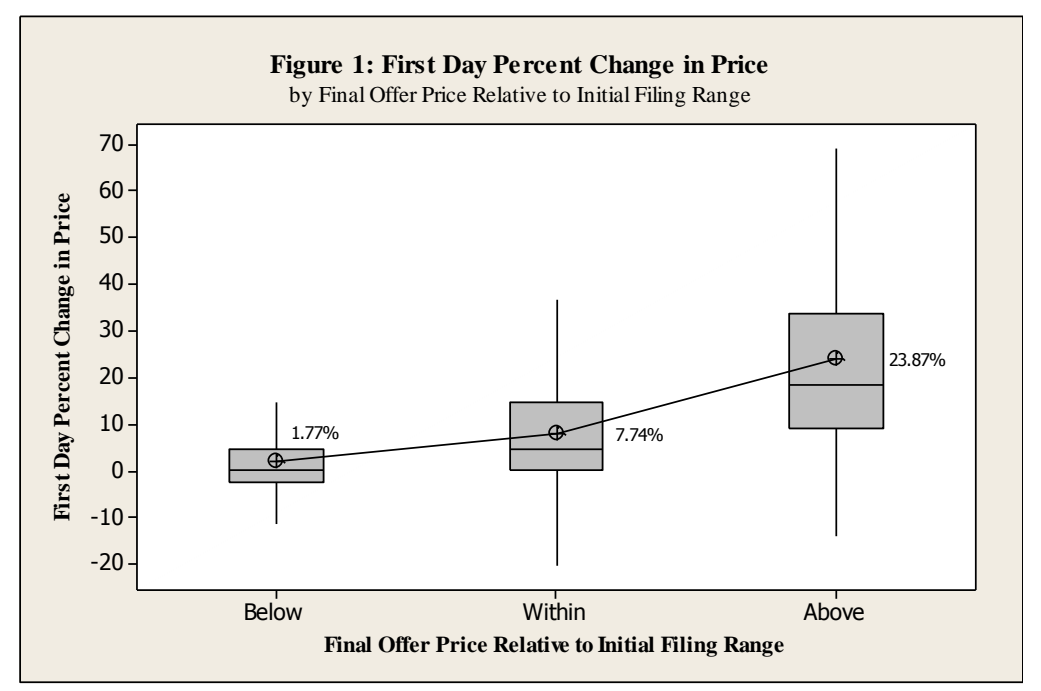

Table 2 shows the distribution of gains, losses and break-evens for FDPCP broken down by whether the final offer price was below, within, or above the initial filing range. This table demonstrates that the distribution of losses, break-evens, and gains varies considerably by the relationship of the final offer price to the initial filing range. For example, if the distribution of losses was independent of the relationship of the offer price to the initial filing range, we would expect to see 67 losses for those IPOs in the below category (20.4\% of 329). In fact, the actual count of 112 is much larger. Similarly, the expected number of gains for those IPOs in the above category is expected to be 229 (70.61\% of 324). The actual value is much larger at 301. In general, it can be concluded that losses are overrepresented and gains are underrepresented in the below category, while the opposite is true for the above category. Once again the data suggest that an investor looking for a one day "flip" should attempt to purchase an IPO where the final offer price is set above the initial filing range.

Table 2: Distribution of Gains, Losses and Break-Evens for FDPCP by Final Offer Price Relative to Initial Filing Range

\begin{tabular}{|c|c|c|c|c|}
\hline & \multicolumn{4}{|c|}{ Final Offer Price Relative to Initial Filing Range } \\
\hline Outcome & Below & Within & Above & Total \\
\hline Loss & $112(34.0 \%)$ & $73(21.7 \%)$ & $17(5.2 \%)$ & $202(20.4 \%)$ \\
\hline Break-Even & $48(14.6 \%)$ & $35(10.4 \%)$ & $6(1.9 \%)$ & $89(9.0 \%)$ \\
\hline Gain & $169(51.4 \%)$ & $229(67.9 \%)$ & $301(92.9 \%)$ & $699(70.6 \%)$ \\
\hline Total & $329(100 \%)$ & $337(100 \%)$ & $324(100 \%)$ & $990(100 \%)$ \\
\hline
\end{tabular}


While the above tables and graph provide useful information about how the value of FDPCP varies with the relationship between the final offer price of the IPO and the initial filing range, a more meaningful analysis considers the impact of other variables that could play a role in determining the value of FDPCP. This was accomplished by constructing a multiple regression model that related FDPCP to six independent variables. These independent variables are described below.

AMOUNT is the product of the number of shares (in millions) in the IPO and the offer price. This is the value of the IPO in millions of dollars. This is the only scale variable in the model besides the dependent variable FDPCP. EXCH is a binary variable set equal to zero if the IPO stock is listed on the NYSE and one if it is listed on the OTC. MARKET is a binary variable set equal to zero if the IPO took place in a bear market and 1 if it took place in a bull market. The years 2002 and 2003 were bear markets, while 2004 to 2007 were bull market years. WITHIN is a binary variable set equal to zero if the offer price is either above or below the initial filing range and one if it is within the initial filing range, while ABOVE is a binary variable set equal to zero if the offer price is either below or within the initial filing range and one if it is above the initial filing range. Finally, the variable YEAR is assigned a value of 1 for IPOs that took place in 2002, up to the value of 6 for IPOs that took place in 2007. These variables are described in Tables 3 through 5.

Table 3: Frequencies for Binary Variables in the Initial Model

\begin{tabular}{|c|c|c|}
\hline Variable & Value = & Value = 1 \\
\hline Exch & 378 (NYSE) & 812 (OTC) \\
\hline Market & 161 (BEAR) & 337 \\
\hline Within & 653 & 324 \\
\hline Above & 666 & (BULL) \\
\hline
\end{tabular}

Table 4: Frequencies for YEAR

\begin{tabular}{|c|c|}
\hline YEAR & Frequency (Number of IPOs) \\
\hline $1(2002)$ & 81 \\
\hline $2(2003)$ & 80 \\
\hline $3(2004)$ & 229 \\
\hline $4(2005)$ & 196 \\
\hline $5(2006)$ & 198 \\
\hline $6(2007)$ & 206 \\
\hline
\end{tabular}

Table 5: Descriptive Statistics for Independent Variables in the Initial Model

\begin{tabular}{|c|c|c|}
\hline Variable & Mean & Standard Deviation \\
\hline Amount & 210.1 & 358.2 \\
\hline Exchange & 0.6182 & 0.4861 \\
\hline Market & 0.8374 & 0.3692 \\
\hline Within & 0.3404 & 0.4741 \\
\hline Above & 0.3273 & 0.4695 \\
\hline Year & 3.9778 & 1.5248 \\
\hline
\end{tabular}

\section{RESULTS}

The results from regressing FDPCP on the six independent variables in the model are presented in Table 6. This table shows that the full model has significant explanatory power, with a computed value of $F=64.73$ ( $p$-value $=0.000$ ). Furthermore, the full model accounts for $27.9 \%$ of the variation in FDPCP, after adjusting for the number of independent variables. 
Table 6: Regression Results

\begin{tabular}{|l|c|c|c|c|}
\hline \multirow{2}{*}{ Constant } & \multicolumn{2}{|c|}{ Full Model } & \multicolumn{2}{c|}{ Restricted Model } \\
\cline { 2 - 5 } & $\begin{array}{c}\text { Estimated } \\
\text { Coefficients }\end{array}$ & $\begin{array}{c}\text { T-statistics } \\
\text { (p-values) }\end{array}$ & $\begin{array}{c}\text { Estimated } \\
\text { Coefficients }\end{array}$ & $\begin{array}{c}\text { T-statistics } \\
\text { (p-values) }\end{array}$ \\
\hline Exch & -1.699 & $-0.98(0.329)$ & -2.537 & $2.45(0.146)$ \\
\hline Amount & 2.128 & $2.02(0.044)$ & 2.649 & \\
\hline Market & -0.002 & $-1.43(0.153)$ & & \\
\hline Within & 0.570 & $0.30(0.761)$ & & $5.008)$ \\
\hline Above & 6.220 & $5.30(0.000)$ & 6.211 & $18.77(0.000)$ \\
\hline Year & 22.316 & $18.78(0.000)$ & 22.230 & $1.89(0.060)$ \\
\hline Adjusted R-squared & 0.489 & $1.08(0.280)$ & 0.594 & 0.279 \\
\hline F statistic (p-value) & \multicolumn{2}{|c|}{0.279} & & $95.63(0.000)$ \\
\hline
\end{tabular}

Even though the evidence from the sample shows that the full model has significant explanatory power, an examination of the t-statistics for the individual regressors indicates that there is no statistical justification for the inclusion of two of the independent variables in the model. MARKET and AMOUNT both have t-ratios with pvalues in excess of 0.10 .

An iterative approach was used to arrive at a restricted model. The independent variable with the largest pvalue was removed from the full model and the estimation procedure was repeated. Two iterations resulted in the removal of MARKET and AMOUNT from the model. The final or restricted regression equation contains only those independent variables with estimated coefficients that have t-ratios with p-values of 0.10 or less.

With the exception of having two fewer independent variables, the full and restricted models are quite similar. The value of adjusted $r$-squared for the restricted model is 0.279 , which is identical to that of the full model. The estimated coefficients on two of the independent variables found in the restricted model, WITHIN and ABOVE, are almost indistinguishable from those found in the full model. The regression coefficient for WITHIN in the restricted model is 6.211, while it is 6.220 in the full model. Likewise, the restricted model regression coefficient for ABOVE is 22.230, as opposed to 22.316 in the full model. This similarity can be attributed to these independent variables being uncorrelated with any other independent variables in the model.

However, the same is not true for the regression coefficients for EXCH and YEAR. For EXCH, the estimate from the restricted model is approximately $25 \%$ larger than the estimate from the full model, 2.649 versus 2.128. Similarly, the regression coefficient for YEAR is about $20 \%$ larger in the restricted model than in the full model. This suggests that both EXCH and YEAR must have been related to the independent variables removed from the full model.

It appears likely that the effects of MARKET are at least partially captured by YEAR, since the first two years in the sample (2002 and 2003) were bear markets, while the remaining four years (2004 to 2007) were bull markets. The explanatory power for AMOUNT may be attributed to EXCH in the restricted model as well. The mean amount of the offering differs significantly depending on the exchange where the issue occurred. The mean offering amount on the NYSE over the time period covered the sample was $\$ 367$ million, compared to $\$ 113$ million for issues on the OTC.

The important statistics for the overall evaluation of the restricted model can be found in Table 6. The computed value of $\mathrm{F}=95.63$ and corresponding $\mathrm{p}$-value $=0.000$ indicate that this model has significant explanatory power. It explains $27.9 \%$ of the variation in FDPCP, after accounting for the number of independent variables in the model. The remaining variation in FDPCP is unexplained by the model, and this unexplained variation can be attributed to the influence of omitted variables, randomness, and "animal spirits."

The only variables from the full model that are significant at the ten percent level are EXCH, WITHIN, ABOVE, and YEAR. If every independent variable in the model was set equal to zero (stock to be traded on NYSE, final offer price below the initial filing range, IPO issued in 2001), the expected value for FDPCP is $-2.537 \%$. 
Holding all other variables constant, if the stock is to be traded on the OTC, the expected value for FDPCP is increased by $2.649 \%$. Similarly, if the final offer price was within the initial filing range, the expected value for FDPCP is increased by $6.211 \%$, while if it was above the initial filing range, the expected value for FDPCP is increased by $22.230 \%$. Finally, with the passing of each year, FDPCP is expected to increase by $0.594 \%$. This annual increase in FDPCP could be due to the pattern of bear and bull markets during the time period that was analyzed. The first two years of the sample data were bear markets and the last four years were bull markets. Furthermore, the worst bear market was 2002, the first year of the sample, and the strongest bull market was 2007, the last year of the sample. Thus, for an investor wishing to maximize FDPCP, it appears that the best decision is to select an IPO where the stock is to be traded on OTC and the final offer price is set above the initial filing range.

\section{DISCUSSION OF RESULTS}

The purpose of this paper is to determine if underwriters create value when they set the final issue price for an IPO. The empirical evidence is clear that they do create value. Given this result, it is interesting to ask which party to the IPO transaction benefits from this value creation. Since the creation of value is a result of the prevalent and systematic underpricing of IPOs, identifying the parties to the IPO transaction who benefit directly from this underpricing should provide an answer. Surprisingly, all three parties appear to gain value from the underpricing of IPOs, which helps explain why it is so pervasive.

The issuing company benefits from underpricing despite the fact that it results in a substantial amount of money left on the table. This resulting increased stock liquidity and share turnover provide value to the issuing firm, but perhaps the most important consequence is the positive "buzz" associated with a successful issue. This is especially important if the firm anticipates floating additional shares in the future.

A successful offer benefits the underwriter through enhanced reputation, which can result in obtaining future business. Additionally, underpricing makes it easier to market the issue, which greatly improves the probability of success of the offering. Moreover, investment bankers determine the actual allocation of the newly issued shares. This allows the banker to reward favored customers, which should also result in future business. In addition to the fees (usually 7\%), a Green Shoe or overallotment option is frequently made available to underwriters. This allows them to short the issue and cover the short position following the offering by acquiring up to a specified number of shares from the issuer at the offer price.

Perhaps the most obvious advantage of underpricing accrues to the investor who receives an initial allocation of shares of an issue where the offer price is above the initial filing range. The results of the regression analysis in this study show that if such a share is sold on the first day of the issue, the expected first day percent change in price is about $22 \%$, ceteris paribus. Since the key to success in this case is to acquire an allocation of these shares, an important area for future research is how this allocation is determined.

For those IPOs where the final offer price was set above the initial filing range, 93\% experienced a positive first day percent change in price. This compares favorably with those IPOs where the final offer price was set below the lower end of the filing range (a success rate of 51\%), or set within the initial filing range (a success rate of 68\%). Evidently, underwriters learned from the bookbuilding process that initial ranges on some IPOs were priced too low while others were priced too high. It appears that underwriters were able to identify which offerings would be more successful, so they set the price above the initial filing range. Likewise, they were also able to identify some offerings that would be less successful, resulting in a final offer price set below the initial filing range.

\section{CONCLUSIONS}

Several conclusions may be drawn from this study of IPO pricing. First, investors may conclude that their interest will be best served, if they restrict buying to instances when the offer price is set above the upper range provided in the "red herring' prospectus. As shown earlier, IPOs in this category experienced a first day price increase more than $90 \%$ of the time, while a first day price decrease occurred only about $5 \%$ of the time. For investors who purchased IPOs with offer prices set below the lower value of the initial filing range, first day gains occurred over $50 \%$ of the time. However, these investors also experienced first day losses over $34 \%$ of the time. 
Second, we can conclude that underwriters do learn from the bookbuilding process, although perhaps they do not learn enough. Of the 990 IPOs in the sample, 337 or about $34 \%$ maintained the price in the initial range. In other words, the majority of offer prices were changed as a result of going through the bookbuilding process. If the initial price range was the best guess, then intuitively raising the offer price would tend to produce more failures, while lowering the offer price would tend to produce fewer losses. However, the data support the opposite conclusion. If a successful IPO is defined as one that does not close below its initial price range on the first day of trading, then underwriters clearly are putting the information obtained by the bookbuilding process to work in setting the price.

The third conclusion is that when the underwriter proposes a final offer price above the initial price range, the issuing company can reasonably expect that the offering will be more successful than originally planned. Conversely, if the final offer price is set below the initial filing range, it can be concluded that there is a greater probability of an unsuccessful offering. This is in spite of the fact that setting the price range is a joint decision between the underwriter and the issuer. This presents a conundrum for the issuing firm. If the final offer price is set above the initial filing range, perhaps the company should demand an even higher price in order to leave less money on the table. If the final offer price is set below the initial filing range, perhaps the issuing firm will want to lower the price even further to ensure a successful offering, thus avoiding the negative publicity associated with a "busted issue."

The fourth conclusion is that the exchange where the shares are issued plays a significant role in determining the first day percent change in price. Shares issued on the OTC can be expected to outperform those issued on the NYSE, ceteris paribus. This may reflect the greater proportion of tech stocks on the OTC. Certainly this is an area that warrants additional research. Other factors specific to the issuing firm may also play a role, such as age, asset size, underwriter quality, and industry.

The final conclusion reached is that the first day performance of IPOs doesn't seem to depend on the market regiment (bull or bear) or the amount of the issue. In addition to the importance of the exchange where the shares are issued, the other factors that influence the value of the first day percent change in price are the relationship between the final offer price and the initial filing range, along with the year of the issue. However, as previously noted, the year of issue could be capturing the effect of market conditions, since the 2002-2003 time period was a bear market, while the remaining four years of the sample data were bull markets.

\section{REFERENCES}

1. Adams, Michael, Barry Thornton and George Hall (2008). "IPO pricing phenomena: Evidence of behavioral biases," Journal of Business and Economics Research 6(4), May, 2008:67-74.

2. Aggarwal, Reena (2003). "Allocation of initial public offerings and flipping activity," Journal of Financial Economics. 68(1), 2003:111-135.

3. Aggarwal, Reena, and Pat Conroy (2000). "Price discovery in initial public offerings and role of the lead underwriter," Journal of Finance, 55(6), December, 2000:2903-2922.

4. Aggarwal, Reena, N. Prabhala, and Manju Puri (2002). "Institutional allocation in initial public offerings: Empirical evidence," Journal of Finance, 57(3) June, 2002:1421-1442.

5. Aggarwal, Reena, Ricardo Leal and Leonardo Hernandez (1993). "The aftermarket performance of Initial Public Offerings in Latin America," Financial Management 22, Spring 1993:42-53.

6. Akerlof, George A. (1970). "The market for "Lemons"; Quality uncertainty and the market mechanism," The Quarterly Journal of Economics, 84(3) Aug., 1970, 488-500.

7. Allen, F. and G. Faulhaber (1989). "Signaling by underpricing in the IPO market," Journal of Financial Economics 23, 303-323.

8. Ang, James S. and Shaojun Zhang (2006). "Underwriting relationships: Information production costs, underwriting fees, and first mover advantage," Review of Quantitative Finance and Accounting, Sept., 2006:205-229.

9. Baron, David P. (1982). "A model of the demand for investment banking advising and distribution services for new issues," Journal of Finance 37, 955-976. 
10. Baron, David P. and B. Holmstron (1980). "The investment banking contract for new issues and asymmetric information: Delegation and the incentive problem," Journal of Finance 35, 1115-1138.

11. Beatty, Randolph and Jay Ritter (1986). "Investment banking, reputation, and the underpricing of initial public offerings," Journal of Financial Economics 15(1-2):213-232.

12. Benveniste, Lawrence M. and Paul A. Spindt (1989). "How investment bankers determine the offer price and allocation of new issues," Journal of Financial Economics 24, 343-362.

13. Benveniste, Lawrence M., and Walid Y. Busaba (1997). "Bookbuilding vs. fixed price: An analysis of competing strategies for marketing IPOs," Journal of Financial and Quantitative Analysis 32, 383-403.

14. Benveniste, Lawrence M., Walid Y. Busaba and William J. Wilhelm, Jr. (1996). "Price stabilization as a bonding mechanism in new equity issues," Journal of Financial Economics 42, 223-256.

15. Boehmer, Beatrice and Ekkehart Fish (2006). "Do institutions receive favorable allocations in IPOs with better long-run returns?" Journal of Financial and Quantitative 41(4), Dec., 2006:809-828.

16. Booth, James and Lena Chua (1996). "Ownership dispersion, costly information, and IPO underpricing," Journal of Financial Economics 41, 291-310.

17. Bradley, Daniel and John Cooney (2006). "Penny stock IPOs," Financial Management 35(1), Spring 2006:5-29.

18. Bradley, D.J. and B.D. Jordan (2002). "Partial adjustment to public information and IPO underpricing," Journal of Financial and Quantitative Analysis 37, 2002:595-616.

19. Brennan, Michael J. and J. Franks (1997). "Underpricing, ownership and control in initial public offerings of equity securities in the UK," Journal of Financial Economics 45, 391-413.

20. Chahine, Salim and Igor Filatotchev (2008). "The effects of information disclosure and board independence on IPO discount," Journal of Small Business Management 46(2), April, 2008:219-241.

21. Chung, Kee H., Mingsheng Lu and Linda Yu. (2005)."Assets in place, growth opportunities, and IPO returns," Financial Management 34(3), Autumn 2005:65-88.

22. Cornelli, Francesca, and David Goldreich (2001). "Bookbuilding and strategic allocation, "Journal of Finance, 56(6): 2337-2370.

23. Cornelli, Francesca and David Goldreich (2003). "Bookbuilding: How informative is the order book?" Journal of Finance, 58(4):1415-1443.

24. Daily, Catherine, Trevis Certo, Dan Dalton and Rungpen Roengpitya (2003). "IPO underpricing: A metaanalysis and research synthesis," Entrepeneurship: Theory and Practice 27(3), Spring 2003:271-295.

25. Derrien, Francois, and Kent Womack (2002). "Auctions vs. bookbuilding and the control of underpricing in hot IPO markets," Review of Financial Studies, 16(1), 2002: 31-61.

26. Drake, Philip D. and Michael Vetsuypens. (1993). "IPO underpricing and insurance against legal liability," Financial Management 22(1), Spring 1993:64-73.

27. Fishe, Raymond P.H. and Ekkehart Boehmer (2001). "Equilibrium rationing in Initial Public Offerings of equity," Retrieved December 16, 2007 from SSRN: http://ssrn.com/abstract=273610, June 14, 2001.

28. Garfinkel, Jon A.. (1993). "IPO underpricing, insider selling and subsequent equity offerings: Is underpricing a signal of quality," Financial Management, Spring 1993:74-83.

29. Grinblatt, M. and C. Hwang (1989). "Signaling and the pricing of new issues," Journal of Finance 44, 393420.

30. Guo, ReJin (2005). "Information collection and IPO underpricing," Review of Quantitative Finance and Accounting 25(1), Aug., 2005:5-19.

31. Habib, Michel, and Alexander Ljungqvist (2001). "Underpricing and entrepreneurial wealth losses in IPOs: Theory and evidence," Review of Financial Studies 14, 433-458.

32. Hanley, Kathleen Weiss (1993). "The underpricing of initial public offerings and the partial adjustment Phenomenon," Journal of Financial Economics 34, 231-250.

33. Hanley, KathleenWeiss and William J. Wilhelm, Jr. (1995). "Evidence on the strategic allocation of initial public offerings," Journal of Financial Economics 37, 239-257.

34. Harper, Joel T. and Jeff Madura. (2002). "Sources of hidden value and risk within tracking stock," Financial Management 31(3), Autumn 2002:91-109.

35. Hoovers.com. Retrieved April 10, 2008 http://www.hoovers.com.

36. Ibbotson, Roger G., Jody L. Sindelar, and Jay R. Ritter (1994). "The market's problems with the pricing of Initial Public Offerings," Journal of Applied Corporate Finance, 7(1), Spring, 1994:66-74. 
37. Jagadeesh, H, M. Weinstein and I. Welch (1993). "An empirical investigation of IPO returns and subsequent equity offerings," Journal of Financial Economics 34, 153-175.

38. Jenkinson, Tim and Alexander Ljungqvist (2001). Going Public: The theory and evidence on how companies raise equity finance (2nd edition), Oxford University Press.

39. Kim, Moonchul and Jay Ritter (1999). "Valuing IPOs," Journal of Financial Economics 53(3), September 1999:409-437.

40. Krigman, L., W. Shaw, and K. Womack (1999). "The persistence of IPO mispricing and the predictive power of flipping," Journal of Finance 54, 1015-1044.

41. Krigman, L., W. Shaw, and K. Womack (2001). "Why do firms switch underwriters?” Journal of Financial Economics 60, 245-284.

42. Lee, Philip J., Stephen L. Taylor and Terry S. Walter (1999). "IPO underpricing explanations: Implications from investor application and allocation schedules," Journal of Financial and Quantitative Analysis 34, 425-444.

43. Leland, H., and D. Pyle (1977). "Informational asymmetries, financial structure, and financial intermediation," The Journal of Finance, 32(2), May, 1977:371-387.

44. Ljungqvist, Alexander, and William Wilhelm (2002). "IPO allocations: discriminatory or discretionary?" Journal of Financial Economics, January, 2002. Retrieved December 1, 2007 from SSRN: http://ssrn.com/abstract=263927.

45. Loughran, Tim and Jay R. Ritter (1995). "The New Issues Puzzle," Journal of Finance 50(1), March, 1995:23-51.

46. Loughran, Tim, and Jay Ritter, (2002). "Why don't issuers get upset about leaving money on the table in IPOs?" Review of Financial Studies 15(2), March 2002:413-444.

47. Lowry, Michelle and William Schwert (2004). "Is the IPO pricing process efficient?" Journal of Financial Economics 71 (2004):3-26.

48. Michaely, R. and W. Shaw (1994). "The pricing of IPOs: Tests of adverse selection and signaling theories", Review of Financial Studies 7, 279-317.

49. Muscarella, Chris J. and Michael R. Vetsuypens (1989). “A simple test of Baron's model of IPO underpricing," Journal of Financial Economics 24, 125-136.

50. Parlour, Christine and Uday A. Rajan (2005). "Rationing in IPOs," Review of Finance 9(1), March, 2005:33-63.

51. Renaissance Capital, IPOhome.com Retrieved April 7, 2008, from http://www.ipohome.com

52. Ritter, Jay (2008). "Analyst behavior following IPOs: The "Bubble Period" evidence," Review of Financial Studies 21(1), January, 2008:101-133.

53. Ritter, Jay (2008). "Some factoids about the 2007 IPO market," March, 2008. Retrieved April 1, 2008 from http://bear.cba.ufl.edu/ritter/ipodata.htm.

54. Ritter, Jay and Ivo Welch (2002). “A review of IPO activity, pricing and allocations," Journal of Finance 57(4), 2002:1795-1828.

55. Rock, Kevin, (1986). "Why new issues are underpriced," Journal of Financial Economics 15, 187-212.

56. Stougton, N. and M. Zechner (1998). "IPO mechanisms, monitoring and ownership structure," Journal of Financial Economics 49, 45-77.

57. Tinic, S. (1988). "Anatomy of Initial Public Offerings of common stock," Journal of Finance 43, 789-822.

58. Welch, Ivan (1989). "Sequential sales, learning and cascades," Journal of Finance 47, 695-732. 
NOTES 